\title{
Abnormal Bleeding Indicator
}

National Cancer Institute

\section{Source}

National Cancer Institute. Abnormal Bleeding Indicator. NCI Thesaurus. Code C154889.

An indication as to whether there is the presence of abnormal bleeding. 